\title{
PERBEDAAN INFORMASI CITRA SEKUEN THICK-SLAB SINGLE-SHOT FAST SPIN ECHO (SS-FSE) DAN SEKUEN 3D-FAST SPIN ECHO (FSE) PADA PEMERIKSAAN MAGNETIC RESONANCE CHOLANGIOPANCREATICOGRAPHY (MRCP)
}

\author{
${ }^{1}$ Anisa Nur Istiqomah, ${ }^{2}$ Hermina Sukmaningtyas, ${ }^{3}$ Luthfi Rusyadi \\ ${ }^{1}$ Stikes Aisyiyah Yogyakarta \\ ${ }^{2}$ Poltekkes Kemenkes Semarang/FK UNDIP \\ ${ }^{3}$ Poltekkes Kemenkes Semarang
}

e-mail: $\underline{\text { anisa.rr28@gmail.com }}$

\begin{abstract}
Backgroud:There are sequences that have the same image and assessment functions are sequences thick-slab SS- FSE and 3D-FSE. Each hospital uses a different sequences for MRCP examination. Based on the different uses of these sequences carried out research with the aim to determine differences in image information thick-slab SS- FSE and 3D-FSE sequences and also to see better sequence for MRCP examination.

Methods: Type of this research is quantitative with observation approach. Ten patient have diagnose system biliaris and pancreas disease undergo MRCP with thick-slab SS-FSE and 3D-FSE sequence. Assessment images information using questionnaire that were read by three radiologist. Inter observer agreement examined by Cohen's Kappa test. Analysis to discover the different of anatomy information, conspicuity of lesion, and artifact using cross tabulation and Wilcoxon test. To discover better sequence observe the mean rank of wilcoxon test.

Results: Result of this research demonstrate that there's significantly different between sequence thick-slab SSFSE and 3D-FSE toward anatomy information $p=0,010$; conspicuity of lesion $p=0,013$; artifact $p=0,008$; Cystic Duct $\mathrm{p}=0,157$; intra hepatic duct $\mathrm{p}=0,405$.

Conclusion:There are significant image informationdifferences of Thick-slab SS-FSE and 3D-FSE sequences in MRCP examination.Better sequence for MRCP examination is thick-slab SS-FSE because short acquisition time and less artifact also showing conspicuity of lesion clearly. Sequence 3D-FSE still used to see small ductus as intra hepatic duct.
\end{abstract}

Keywords :Thick-slab SS-FSE, 3D-FSE, MRCP

\section{Pendahuluan}

Magnetic

Cholangiopancreaticography
Resonance

(MRCP) adalah pemeriksaan yang memberikan detail informasi anatomi dan patologi dari biliary tree dan pancreatic duct yang mengkombinasikan cross- sectional dan projectional technique dimana umumnya dilakukan dengan sekuen heavily T2-weighted untuk memperlihatkan cairan statis seperti yang terdapat dalam pelebaran pancreas dan saluran empedu (Lavdas,2013). 


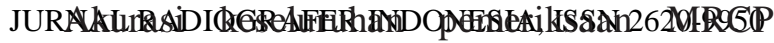

dalam evaluasi batu saluran empedu sangat tinggi dengan sensitivitas dan spesifitas mulai dari 96 sampai $100 \%$
(Soto JA,2000). Aplikasi utama MRCP adalah evaluasi obstruksi biliari karena choledocholithiasis, cholangiocarcinoma, karsinoma pankreas. dan penilaian fungsi eksokrin pankreas setelah stimulasi sekretin (Maccioni,2010).

Terdapat tiga cara untuk mendapatkan citra MRCP yaitu (1) multi-slice 2 dimensi Fast Spin Echo/Turbo Spin Echo dengan Half-Fourier Acquired K-space (single-shot FSE/TSE), sering disebut sekuen T2- weighted 2D Half-FourierAcquired Single-Shot (SS) TSE (HASTE). (2) Single-Slice Thick-slabSingle-Shot Fast Spin Echo (SS-FSE/TSE) RARE. Cara lainnya yaitu menggunakan 3D MRCP, yang menggunakan high resolution sekuen 3D T2-weighted FSE/TSE 
dengan voxel seragam dan navigator trigger

(Manfredi,2013).

Single-Shot Fast Spin Echo (SS-FSE) atau HalfFourier Acquisition Single Shot Turbo Spin Echo (HASTE) adalah salah satu sekuen yang digunakan untuk menghasilkan citra MRCP menggunakan teknik partial $K$-space filling sehingga mampu menghasilkan citra dengan waktu scanning yang singkat, 1-2 detik untuk teknik single-slice dan 18 detik untuk teknik multi-slice. Teknik thick-slab single-shot adalah kombinasi sekuen Fast Spin Echo dengan slice thickness yang tebal $(30-80 \mathrm{~mm})$ yang dapat diperoleh pada berbagai bidang (radial slab) menggunakan single-shot breath-hold sehingga hasil citra MRCP mirip dengan proyeksi radiografi Endoscopic

Retrograde

Cholangiopancreaticography

(ERCP)

(Manfredi,2013). Single-shot projection sesuai untuk pasien yang tidak dapat menahan napas dengan baik seperti pasien dengan penyakit parah atau anak kecil (Ringe, 2014).

Sekuen T2-Weighted 3D-FSE/TSE merupakan salah satu sekuen yang disarankan untuk pemeriksaan MRCP selain sekuen SS-FSE dimana sekuen 3D-FSE dianggap sebagai alternatif untuk menilai ketepatan dalam keraguan diagnose dan mendeskripsikan kelainan atau variasi dari biliary tree dan pancreatic duct. Sekuen 3D-FSE didapatkan dengan slice thickness tipis tanpa intersection gaps (Manfredi,2013). Program 3D volumetric data dapat dengan mudah ditransformasi pada potongan coronal, sagital, coronal oblik atau kurva cross sectional yang dapat membantu mendeteksi dan menemukan letak lesi. Maximum Intensity Projection (MIP) memungkinkan menampilkan citra 3D dari biliary tree dan pancreatic duct dengan hasil gambaran mirip dengan ERCP (Julardzija,2014).

Zhang (2005) menyatakan bahwa 3D MRCP memiliki kemampuan jauh lebih baik dalam menggambarkan system pancreaticobiliary dibandingkan dengan gambaran 2D konvensional, akan tetapi penelitian ini tidak menggunakan sekuen SS-FSE melainkan 2D TSE konvensional. Goh (2012) menyatakan bahwa 3D-FSE tidak meningkatkan akurasi diagnostik dalam mendeteksi choledocholithiasis.

Penggunaan sekuen untuk pemeriksaan MRCP disetiap rumah sakit berbeda-beda. Terdapat rumah sakit hanya menggunakan sekuen 3D-FSE atau thickslab SS-FSE saja sebagai protokol pemeriksaan MRCP, namun ada yang memilih kedua sekuen tersebut dipakai untuk pemeriksaan.

Tujuan dari penelitian ini adalah Untuk mengetahui perbedaan informasi citra sekuen thick-slab SS-FSE dan 3D-FSE pada pemeriksaan MRCP. Selain itu bertujuan untuk mengetahui sekuen yang lebih baik dalam menampilkan informasi citra MRCP.

\section{METODE}




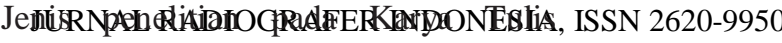

Ilmiah ini adalah penelitian kuantitatif dengan pendekatan observasional yang bertujuan untuk mengetahui perbedaan informasi citra sekuen thick-slab SS-FSE dan 3D-FSE pada pemeriksaan MRCP.

Sepuluh pasien yang menjalani pemeriksaan MRCP di Unit Radiologi RSUP dr. Hasan Sadikin Bandung sebagai sampel penelitian terkait. Sampel penelitian ini harus memenuhi syarat kriteria inklusiyaitu : 1) berumur sekitar 30-70 tahun, 2) sampel mampu menahan napas kurang lebih selama 25 detik, 3) sampel bersedia menjalani pemeriksaan dan mengikuti jalannya penelitian. Sampel tidak termasuk pasien claustrophobia. Responden yang memberikan penilaian terhadap citra MRCP adalah 3 (tiga) orang dokter spesialis radiologi.

Prosedur dalam penelitian ini adalah:

1. Pasien puasa 6 jam sebelum pemeriksaan MRCP dan melakukan latihan tahan napas selama 25 detik.

2. Pembuatan citra MRCP diawali dengan membuat 3 plane localizer.

3. Dilakukan pembuatan citra MRCP menggunakan sekuen T2-WI axial HASTE dan T2-WI coronal HASTE.

4. Hasil citra sekuen T2-WI HASTE digunakan sebagai scan plane citra selanjutnya.

5. Setiap sampel dilakukan scanning dengan dua sekuen berbeda yaitu sekuen thick-slab SS-FSE dan 3DFSE.

6. Citra hasil penelitian tersebut dicetak menggunakan film tanpa ada keterangan identitas apapun, hanya diberikan kode serial citra.

7. Tiga orang dokter spesialis radiologi yang berpengalaman di bidang MRI 1.5 Tesla dimohon untuk mencermati citra dari masing-masing gambar.
Penilaian kualitatif berupa menilai kejelasan anatomi secara umum, kejelasan per kriteria anatomi (Gall bladder, Cystic Duct, Common Hepatic Duct, Intra Hepatic Duct, Common Bile Duct, Main Pancreatic Duct), kejelasan lesi, dan artefak serta memilih sekuen yang lebih baik dari dua variasitersebut.

8. Penilaian dokter spesialis radiologi dilakukan dengan memberikan tanda check $(\sqrt{ })$ pada kuisioner yang telah disediakan. Pertanyaan tentang kejelasan citra diberikan nilai $\mathbf{3}$ dengan arti sangat baik, bila informasi citra tegas, terang, mudah dilihat oleh observer. Nilai 2 dengan arti cukup baik, bila informasi citra tampak, namun tidak sejelas yang diberi nilai 3 . Nilai 1 dengan arti kurang baik, bila informasi citra kurang jelas atau bahkan observer sulit 
menemukan informasi yang dimaksud pada citra yang diamati.

Data diolah dan diuji secara komputerisasi menggunakan program SPSS 16.0. Data yang didapat berupa data ordinal, berpasangan, dan menggunakan dua kelompok variabel, diuji dengan Wilcoxon-Signed RankTest untuk menilai ada tidaknya perbedaan yang signifikan pada dua sekuen tersebut dengan tingkat kemaknaan $95 \%$. Untuk menilai sekuen yang lebih baik pada pemeriksaan MRCP dapat dilihat pada Mean rank yang tertera pada hasil pengujian Wilcoxon-Signed Rank Test.

\section{Hasil dan Pembahasan}

Penelitian dilakukan terhadap 10 (sepuluh) pasien berjenis kelamin pria dan wanita, rentang usia antara

30 tahun sampai 70 tahun dengan 7 orang diduga menderita batu biliaris dan 3 orang menderita tumor.

Tabel 1. Karakteristik Sampel berdasarkan Jenis

\begin{tabular}{lll}
\multicolumn{2}{c}{ Kelamin } \\
\hline Jenis Kelamin & Jumlah & Persentase \\
\hline Laki - Laki & 5 & $50 \%$ \\
Perempuan & 5 & $50 \%$ \\
Total & 10 & $100 \%$ \\
\hline
\end{tabular}

Tabel 2. Karakteristik Sampel berdasarkan Umur Umur Jumlah Persentase

\begin{tabular}{rcc} 
Jumlah & Persentase & \\
\hline $26-35$ & 0 & $0 \%$ \\
$36-45$ & 4 & $40 \%$ \\
$46-55$ & 4 & $40 \%$ \\
$56-65$ & 1 & $10 \%$ \\
$65-70$ & 1 & $10 \%$ \\
Total & 16 & $100 \%$ \\
\hline
\end{tabular}

Tabel 3. Karakteristik Sampel berdasarkan

\begin{tabular}{ccc}
\multicolumn{3}{c}{ Patologis } \\
\hline Patologis & Jumlah & Persentase \\
\hline Batu Biliaris & 7 & $70 \%$ \\
Tumor & 3 & $30 \%$ \\
Total & 10 & $100 \%$ \\
\hline
\end{tabular}

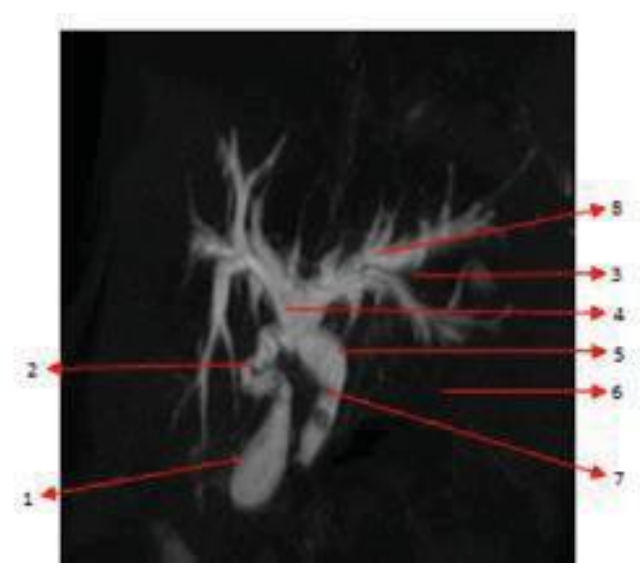

Gambar 1. Citra MRCP potongan coronal sekuen 3DFSE.

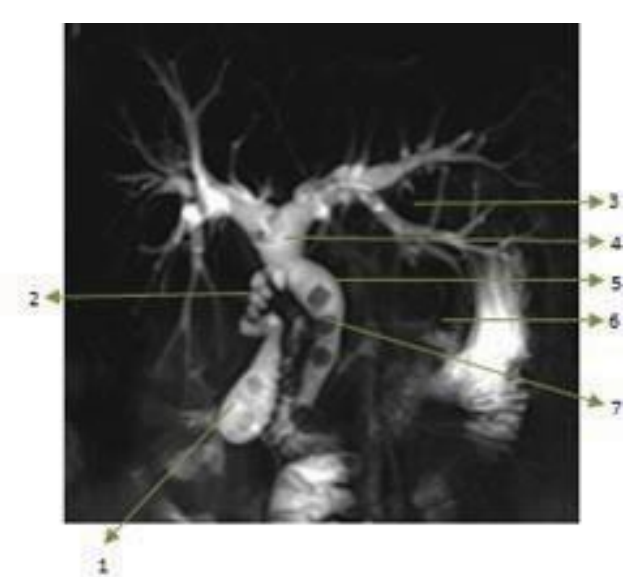

Gambar 2. Citra MRCP potongan coronal sekuen

$$
\text { Thick-slab SS-FSE. }
$$

Keterangan :

Dari kesepuluh pasientersebut diperoleh informasi anatomis MRCP sekuen Thick-slab SS-FSE dan 3D- FSE. Masing-masing sekuen menghasilkan 10 citra yang dapat menampakkan anatomi Gall bladder, Cystic Duct, Common Hepatic Duct, Intra Hepatic Duct, Common Bile Duct, Main Pancreatic Duct, kejelasan lesi, dan artefak.

Di bawah ini merupakan hasil salah satu sampel antara sekuen Thick-slab SS-FSE dan 3D-FSE. 
1. GalJJWRAAL RADIOGRAFER INDONESIA, ISSN 2620-9950

2. Common bile duct

3. Cystic duct

4. Main pancreatic duct

5. Intrahepatic duct

6. Lesi

7. Common Hepatic Duct

8. Motion Artefak

Sebelum dilakukan uji statistik untuk mengetahui perbedaan informasi citra antara sekuen thick-slab SS- FSE dan 3D-FSE, dilakukan pengujian kappa test untuk mengetahui kesesuaian atau kesamaan persepsi responden dalam penilaian kuisioner. Hasil pengujian kappa test terhadap 3 responden sebagai berikut: 
Tabel 4. Hasil Uji Kappa pada Tiga Responden

Tabel 7. Hasil Uji Beda Kejelasan Lesi antara Thick-

\begin{tabular}{|c|c|c|c|c|c|}
\hline \multirow{3}{*}{ Sekuens } & \multicolumn{3}{|c|}{$\begin{array}{c}\text { Tingkat Kesepakatan } \\
\text { Cohen's Kappa }\end{array}$} & \multirow{2}{*}{$\begin{array}{c}\text { Rata } \\
-\end{array}$} & \multirow{3}{*}{$P$ value } \\
\hline & $\mathrm{R} 1 *$ & $\mathrm{R} 1 *$ & $\mathrm{R} 2 *$ & & \\
\hline & $\mathrm{R} 2$ & $\mathrm{R} 3$ & $\mathrm{R} 3$ & Rata & \\
\hline \multirow[t]{2}{*}{ 3D-FSE } & 0,81 & 0,82 & 0,81 & $\mathrm{v}, 01$ & $<0,001$ \\
\hline & $a$ & n & 5 & 7 & \\
\hline SS-FSE & 3 & 3 & 8 & 8 & \\
\hline
\end{tabular}

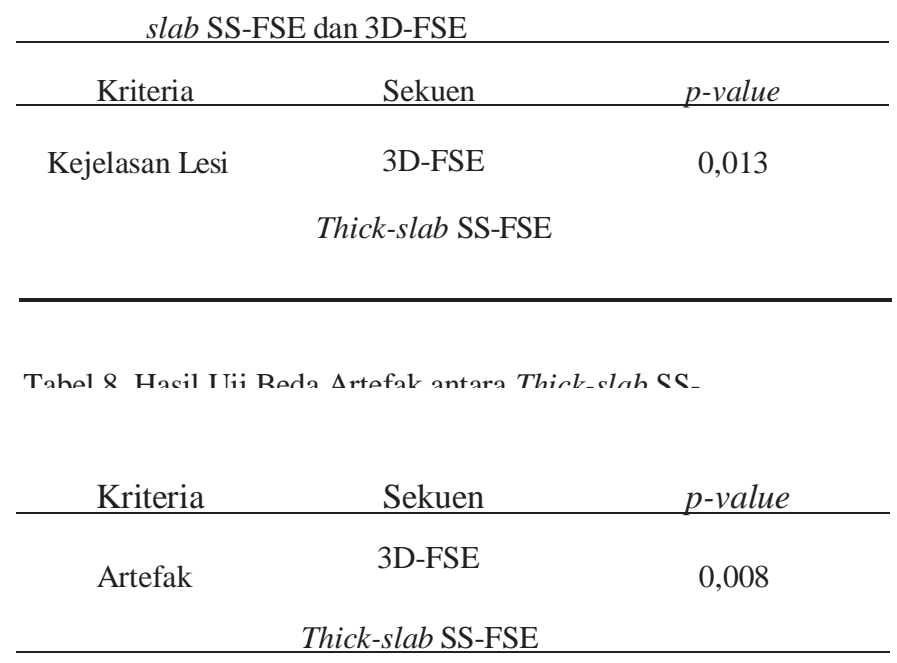

Keterangan :

$\mathrm{R} 1$ : responden $1 ; \mathrm{R} 2$ : responden $2 ; \mathrm{R} 3$ : responden 3 Berdasarkan hasil uji kappa dapat dilihat value kappa pada sekuen 3D-FSE menunjukkan value kappa 0,817 dengan $p$ value $<0,001$ dan untuk Thick-slab SS- FSE menunjukkan value kappa 0,848 dengan $p$ value $<0,001$. Hasil ini menunjukkan bahwa ada kesesuaian atau persamaan persepsi antara ketiga responden dalam menilai informasi citraMRCP pada sekuen Thick-slab SS-FSE dan 3D-FSE. Tingkat persamaan persepsi antar responden memiliki hasil hampir sempurna karena berada pada rentang 0,81-

1.

Uji Beda dilakukan pada Informasi citra per kriteria anatomi, anatomi secara keseluruhan, kejelasan lesi,

dan artefak dengan membandingkan nilai dari kriteria yang dapat dinilai pada sebuah citra MRCP pada sekuen thick-slab SS-FSE dan 3D-FSE. Berdasarkan uji beda yang telah dilakukan, maka didapatkan hasil sebagai berikut :

Tabel 5. Hasil Uji Beda per-kriteria antara Thick-slab

\section{SS-FSE dan 3D-FSE}

\begin{tabular}{ccc}
\multicolumn{2}{c}{ SS-FSE dan 3D-FSE } & p-value \\
\hline Kriteria & Sekuen & 0,005 \\
Gall bladder & 3D-FSE & \\
& Thick-slab SS-FSE & \\
Cystic Duct & 3D-FSE & 0,157 \\
& Thick-slab SS-FSE & \\
Common & Duct Common & Ma \\
Hepatic Duct & Bile Duct & in \\
Intra Hepatic & & $P a$
\end{tabular}

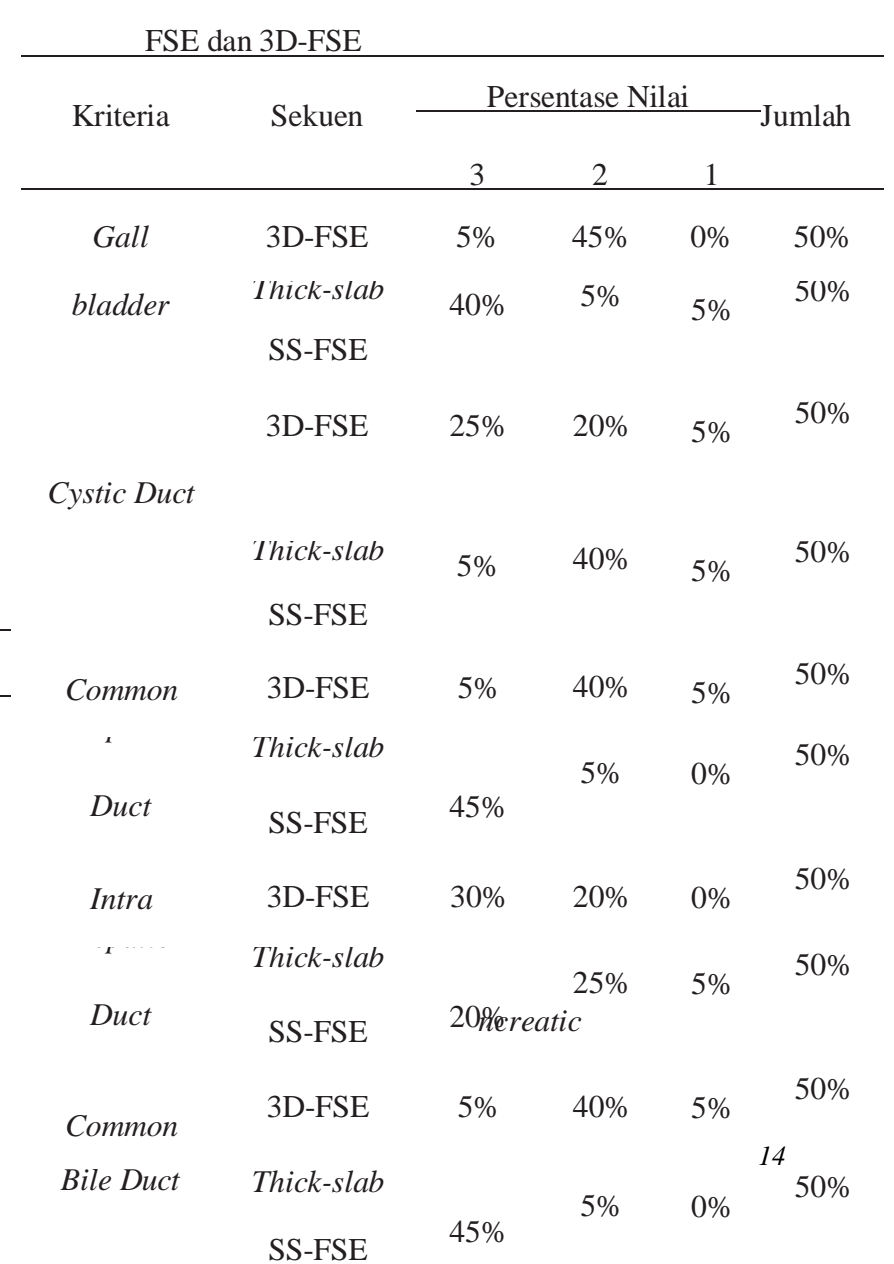

Berdasarkan hasil uji beda $p$ value anatomi keseluruhan 0,010; kejelasan lesi 0,013; artefak 0,008 $(\mathrm{p}<0,05)$, dapat dinyatakan bahwa terdapat perbedaan informasi anatomi keseluruhan, kejelasan lesi, dan artefak antara sekuen Thick-slab SS-FSE dan 3D-FSE pada pemeriksaan MRCP.

Analisis deskriptif dilakukan dengan uji tabulasi silang (cross tabulation) dengan hasil sebagai berikut:

Tabel 9. Hasil Cross tabulationantara Thick-slab SS- 
3ORASAL RADIOGRAFER IRDONESIA, ISSN 2620-9950

Thick-slab SS-FSE

3D-FSE

0,405

Thick-slab SS-FSE

3D-FSE

Thick-slab SS-FSE

0,013

3D-FSE

Thick-slab SS-FSE

0,013

Pancr

eatic

Duct

Berdasarkan tabel 5dapat dinyatakan bahwa terdapat perbedaan informasi citra per kriteria anatomiantara sekuen thick-slab SS-FSE dan 3D-FSE pada pemeriksaan MRCP.

Tabel 6. Hasil Uji Beda Anatomi Keseluruhan antara

Kejelasan

Thick-slab SS-FSE dan 3D-FSE

\begin{tabular}{ccc} 
Kriteria & Sekuen & p-value \\
\hline Anatomi & 3D-FSE & 0,010 \\
Keseluruhan & Thick-slab SS-FSE & \\
\hline
\end{tabular}

SS-FSE 
Tabel 10. Hasil Cross tabulationantaraThick-slab SS-

FSE dan 3D-FSE terhadap Artefak

\begin{tabular}{ccccc} 
& & \multicolumn{2}{c}{ Persentase Nilai } & \multirow{2}{*}{ Jumlah } \\
\cline { 3 - 4 } Kriteria & Sekuen & $\begin{array}{c}\text { Ada } \\
\text { Artefak }\end{array}$ & $\begin{array}{c}\text { Tidak } \\
\text { Ada }\end{array}$ & \\
& & & Artefak \\
Artefak & 3D-FSE & $40 \%$ & $10 \%$ & $50 \%$ \\
& hick-slab SS- & $5 \%$ & $45 \%$ & $50 \%$ \\
& FSE & & & \\
\hline
\end{tabular}

Hasil tabel di atas menunjukkan bahwa persentase nilai sangat baik terdapat pada sekuen thick-slab SSFSE dimana sebagian besar radiolog menjawab sangat baik untuk setiap kritera penilaian.

Untuk menentukan sekuen yang lebih baik menggambarkan informasi citra MRCP antara sekuen thick-slab SS-FSE dan 3D-FSE dilakukan dengan melihat mean rank pada wilcoxon sign test seperti pada tabel 11.

Tabel 11. Hasil Mean Rank Wilcoxon Sign Test

\begin{tabular}{|c|c|c|}
\hline Kriteria & Sekuen & Mean rank \\
\hline \multirow{3}{*}{ Gall bladder } & 3D-FSE & 0,00 \\
\hline & Thick-slab SS-FSE & 4,00 \\
\hline & 3D-FSE & 4,50 \\
\hline Cystic Duct & Thick-slab SS-FSE & 4,50 \\
\hline Common & 3D-FSE & 5,00 \\
\hline $\begin{array}{l}\text { Hepatic Duct } \\
\text { Intra Hepatic }\end{array}$ & Thick-slab SS-FSE & 5,56 \\
\hline $\begin{array}{c}\text { Duct Common } \\
\text { Bile Duct }\end{array}$ & 3D-FSE & 5,83 \\
\hline Main & Thick-slab SS-FSE & 5,00 \\
\hline $\begin{array}{c}\text { Pancreatic } \\
\text { Duct }\end{array}$ & 3D-FSE & 5,00 \\
\hline \multirow{4}{*}{$\begin{array}{c}\text { Anatomi } \\
\text { Keseluruhan }\end{array}$} & Thick-slab SS-FSE & 5,56 \\
\hline & 3D-FSE & 5,00 \\
\hline & Thick-slab SS-FSE & 5,56 \\
\hline & 3D-FSE & 5,00 \\
\hline \multirow[t]{2}{*}{ Kejelasan Lesi } & Thisł-As & 0,56 \\
\hline & Thick-slab-5SE-FSE & 4,50 \\
\hline
\end{tabular}

Berdasarkan mean rank yang dihasilkan, sekuen thick-slab SS-FSE memperoleh nilai mean rank yang lebih tinggi dibandingkan sekuen 3D-FSE kecuali pada kriteria anatomi Cystic Duct memiliki nilai mean rank yang sama yaitu 4,50 dan anatomi Intra Hepatic pancreatic duct yang sebagian besar kandungannya adalah cairan. Terdapat beberapa sekuen yang mampu menampakkan cairan statis dan patologinya dengan teknik berbeda-beda. Pemilihan sekuen yang tepat dapat membantu radiolog menginterpretasi citra secara tepat dan akurat. Hasil uji beda pada informasi citra anatomi keseluruhan menunjukkan nilai $p$ value $<0,010(\mathrm{p}<0,05)$ yang berarti ada perbedaan informasi citra anatomi antara sekuen Thick-slab SSFSE dan 3D-FSE.Hasil uji beda pada informasi citra kejelasan lesi menunjukkan $p$ value $0,013(\mathrm{p}<0,05)$ sehingga ada perbedaan informasi citra kejelasan anatomi antara kedua sekuen tersebut. Begitu juga dengan informasi citra artefak memiliki $p$ value 0,008 $(\mathrm{p}<0,05)$ yang berarti ada perbedaan informasi citra artefak antara kedua sekuen. Sekuen thick-slab SSFSE dinyatakan sebagai sekuen lebih jelas dalam menampilkan informasi citra anatomi, kejelasan lesi dan artefak sistem pancreaticobiliary. Karakteristik masing-masing sekuen menimbulkan perbedaan yang signifikan secara statistik apabila ditinjau dari kemampuan kedua sekuen melakukan akuisisi citra.

Sekuen Thick-slab SS-FSE dan 3D-FSE

merupakan dua sekuen yang sangat baik dalam

menampakkan citra sistem pancreaticobiliary seperti gambaran pada radiografi ERCP dan menawarkan kelebihan berbeda dibandingkan dengan sekuen konvensional. Kedua sekuen ini memiliki prinsip yang sama yaitu menampakkan cairan statis dengan menggunakan Time Repetition (TR) dan Time Echo (TE) yang sangat panjang. Perbedaannya terdapat pada teknik akuisisi citra. Sekuen Thick-slab SS-FSE menggunakan teknik partial $K$-space imaging dengan sebagian atau setengah $k$-space yang terisi dan sisanya direkonstruksi menggunakan algoritma dengan exploiting $k$-space simetry, sedangkan 3D-FSE menggunakan teknik volume imaging 3 dimensi dengan semua daerah $k$-space terisi atau mengalami phase encoding dengan menggunakan isotropic voxel (Manfredi,2013).

Anatomi Cystic Duct dan Intra Hepatic Duct tidak ada perbedaan informasi citra secara statistik. Tidak

Duct nilai mean rank lebih tinggi dihasilkan oleh sekuen 3DFSE sebesar 5,83 dan sekuen thick-slab SS-FSE sebesar 5,00. Maka dapat dinyatakan sekuen thick-slab SS-FSE lebih jelas dalam menggambarkan informasi citra anatomis Gall bladder, Common Hepatic Duct, Common Bile Duct, main Pancreatic 


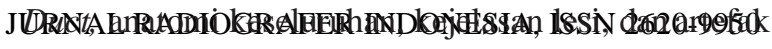
dibandingkan sekuen 3D-FSE.

Citra MRCP mengandalkan teknik pencitraan cairan statis untuk melihat sistem dari biliary tree dan adanya perbedaan tersebut karena struktur anatomi yang variatif dari kedua organ tersebut. Menurut Amirudin (2006) Panjang Cystic Duct bervariasi dapat pendek atau tidak ada karena memiliki penyatuan yang erat dengan Ductus hepaticus. Dapat panjang, di belakang, atau spiral sebelum bersatu dengan Ductus hepaticus communis. Selain itu struktur Cystic Duct dan Intra Hepatic Duct sangat kecil sehingga kurang maksimal menggunakan teknik single-shot. Seperti yang didefinisikan oleh Manfredi (2013) Slice thickness yang tebal dari thick-slab SS-FSE sekuen yang lebih luas dari struktur yang bertindih dapat menurunkan keseluruhan kualitas citra. Analisis detail diagnosa dari sistem biliaris mungkin buruk dipengaruhi oleh efek proyeksi overlying struktur.

Sekuen thick-slab SS-FSE lebih sensitif dalam menampakkan kejelasan lesi. Hal tersebut dapat terjadi karena teknik pengambilan data sekuen thick- 
slab SS-FSE menggunakan slice thickness $50 \mathrm{~mm}$ secara single-shot dan tanpa rekonstruksi. Sedangkan sekuen 3D-FSE, teknik pengambilan citra dengan cara volume imaging mengisi $\mathrm{k}$-space satu per satu setiap garis dengan volumetric voxel.

Menurut Goh (2012) SS-FSE mampu
menampakkan adanya batu pada system biliaris
dengan lebih jelas yang mana dapat tidak terdiagnosa
pada sekuen 3D-FSE. Lavdas (2012) berpendapat
bahwa jumlah batu pada IHBD, CBD, dan Gall
bladder lebih dapat terlihat pada sekuenSS-FSE
dibandingkan dengan 3D-FSE.

Artefak yang dihasilkan pada sekuen 3D-FSElebih banyak karena waktu scanning yang lebih lama. Sehingga mempengaruhi ke hasil cira. Keberadaan artefak pada MRCP lebih sering disebabkan karena motion artefak atau pergerakan pasien saat pernapasan. Penelitian ini menggunakan sekuen 3DFSE dengan teknik breath hold dimana pasien harus menahan napas sampai akuisisi data selesai. Waktu yang diperlukan untuk mendapatkan citra sekuen 3DFSE adalah 25 detik. Sehingga apabila pasien tidak mampu menahan sampai 25 detik maka citra mengalami blurring dan tidak memiliki batas yang tegas. Menurut Glockner (2005) menyebutkan bahwa pada teknik breath hold kerja sama atau tingkat kooperatif pasien sangat dibutuhkan untuk menghindari image blur pada citra. SSekuen Thickslab SS-FSE membutuhkan waktu satu detik untuk setiap citra sehingga waktu yang diperlukan lebih singkat dan sangat mampu meminimalisir adanya motion artefak.

Menurut Manfredi (2013) Keuntungan utama dari sekuen Thick-slab SS-FSE adalah akuisisi citra yang sangat cepat, 1 detik, dan faktanya tidak memerlukan post-processing. Untuk pasien yang sakit parah dengan kapasitas pernapasan yang terbatas, sekuen thick-slab SS-FSE mungkin satu-satunya teknik imaging untuk mendapatkan kualitas citra yang cukup dengan sedikit artefak. Lavdas (2012) menerangkan bahwa visualisasi dari lithiasis dan Pancreatic Duct lebih baik dari citra menggunakan sekuen SS-FSE karena memiliki artefak yang lebih sedikit.

Pada sekuen 3D-FSE yang memiliki banyak motion artefak karena pergerakan pasien sehingga disarankan untuk menggunakan teknik respiratory triggering daripada teknik breath hold karena pasien tidak perlu tahan napas selama 25 detik. Pasien hanya diminta untuk bernapas secara teratur selama akuisisi data. Penggunaan parallel imaging juga dimungkinkan untuk mengurangi waktu scanning namun akan menurunkan SNR sehingga pemilihan acceleration factor harus diperhatikan. Sekuen thick-slab SS-FSE bukan berarti tanpa artefak, terdapat residual fluid dari lambung dan duodenum yang terkadang menutupi anatomi yang ingin dilihat, masalah ini dapat diatasi dengan penggunaan media kontras oral negatif yang mampu menekan sinyal dari lambung dan duodenum. Pada penelitian ini masih terdapat kekurangan yaitu penelitian ini tidak mengukur SNR yang dihasilkan 


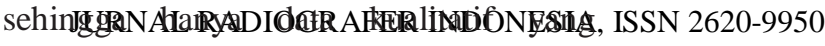

diukur, pengukuran secara kuantitatif tidak dilakukan. Kemudian penelitian ini menggunakan teknik breath hold untuk semua sekuen dan tidak mengukur penggunakan teknik respiratory triggering. Penelitian ini juga tidak menggunakan media kontras oral negatif sehingga masih terdapat residual fluid lambung dan duodenum yang tampak terutama pada sekuen thick- slab SS-FSE.

\section{Simpulan}

Ada perbedaan informasi citra anatomi keseluruhan $p$ value 0,006 ; kejelasan lesi 0,013; artefak 0,008 (p<0,05) antara sekuen Thick-slab SS_FSE dan 3D- FSE pada pemeriksaan MRCP. Sekuen Thickslab SS- FSE lebih baik dalam menampakkan informasi citra pada pemeriksaan MRCP biladibandingkan dengan sekuen 3D-FSE.

Direkomendasikan penggunaan sekuen Thick-slab SS-FSE sebagai sekuen pemeriksaan MRCP.Sekuen 3D-FSE sebaiknya digunakan juga bersama sekuen Thick-slab SS-FSE karena format citra 3 dimensi mampu melakukan rekonstruksi dan mampu melihat organ yang kecil yang tidak terlihat apabila menggunakan Thickslab SS-FSE

\section{Daftar Pustaka}

Amirudin.R.2006. Anatomi Fisiologi dan Biokimia. Hari. Dalam: Aru W.Sudoyo,Bambang Setyohadi, Idrus Alwi, Marceliuss, dan Siti eds. Bertram G.Kaztung I. Edisi 3. Jakarta:EGC.

Glockner, James F, et all.2005.Parallel Imaging: A User Guide.RSNA.

Goh et al.2012.MR

Cholangiopancreaticography: Comparison between 3D Fast Recovery Fast Spin Echo and 2D single shot fast spin echo sequence in the evaluation of choledocholithiasis. Singapore:
European Society of Radiology.

Griffin et al.2011.Magnetic Resonance Cholangiopancreaticography: the $A B C$ of $M R C P$.United Kingdom: European Society of Radiology.

Julardzija et al.2014.Comparison of 3D Maximum intensity projection (MIP) reconstruction and 2D T2 Half-fourier Acquisition Single-Shot Turbo Spin-Echo (HASTE) sequence in magnetic resonance cholangiopanreaticography.Bosnia: Journal of Health Sciences.

Lavdas et al.2013. How Reliable is MRCP with an SSFSE sequence at 3T: comparison between SSFSE BH and 3D-FSE BH ASSET sequence. Greece: Clinical Imaging.

Maccioni,F.et.all.2010.MagneticResonance Cholangiography: Past, Present and Future: A Review.Italy: European review for Medical and Pharmacological Science.

Manfredi, Riccardo, Roberto Pozzi Mucelli.2013.Magnet

ResonanceCholangiopancreaticography.Italia: Spring r- Verlag.

Ringe et al.2014.3D-MRCP for evaluation of intraand extrahepatic bile ducts: comparison of different acquisition and reconstruction planes.Germany:BMC Medical Imaging.

Soto JA, et.all.2000.Biliary obstruction: findings at $M R$ cholangiography and cross-sectional MR imaging.Korea: Weishaupt, Domminik,Victor D.Kochli,Borut Marincek.2008.How Does MRI Work?.Second Edition.Berlin Heidelberg: Springer-Verlag

Westbrook, Kaut.2014. Handbook of MRI Technique.Fourth Edition.UK:Blacwell John Wiley and Sons, Ltd. 
JURNAL RADIOGRAFER INDONESIA, ISSN 2620-9950

Zhang et al.2005.Isotropic 3D T2-

Weighted MR

Cholangiopancreaticography with parallel imaging: Feasibility Study.New York:American Journal of Roentgenology. 